\title{
COMMON MARE'S TAIL (Hippuris vulgaris L.) IN THE ASSESSMENT OF WATER STATUS AND THEIR PHYTOREMEDIATION
}

\author{
Department of Chemistry, Microbiology and Biotechnology of Environment, West Pomeranian \\ University of Technology, Szczecin, Poland \\ 1Department of Ecology, Environmental Protection and Management, West Pomeranian University \\ of Technology, Szczecin, Poland
}

\begin{abstract}
Pollution of aquatic ecosystems continues to be a problem in developed countries, resulting in a reduction in the biodiversity of organisms associated with these habitats. In many countries, macrophyte indices are used to assess surface water pollution. They apply both to determining the ecological status of lakes and rivers. The presence of aquatic plants informs, among others, on the level of water eutrophication, and the analysis of the content of metals in plants indicates the pollution of water ecosystems with metals. Failure to reach the key objective of the Water Framework Directive, i.e. good water status, by 2015 forces the search for new ways of water management, including cheap and environmentally friendly methods of treatment of contaminated and used waters. The results of research on the possibilities and limitations in the functioning of individual species of aquatic plants in polluted and used waters allow for the rational selection of plants for phytoremediation of aquatic ecosystems. The aim of this review was to discuss the biological features of common mare's tail and its habitat and to determine the plant's ability to develop in waters contaminated with biogenic compounds and metals, and to determine its ability to uptake metals measured by the effectiveness of removing contaminants. It was found that mare's tail occurs in waters with variable concentration of biogenic compounds and metals. Irrespectively of the concentration of nitrogen, phosphorus and potassium in the plant growth medium, each introduction of lead, zinc, copper, manganese and iron into the plant growth medium, in quantities corresponding to the limit values for $V$ class water quality, caused their increased uptake by mare's tail. The accumulation of these elements reflects the state of water pollution with metals. Nevertheless, water pollution with some metals causes the biomass of the plant to be reduced. Due to high efficiency of removing various impurities by mare's tail, the plant can be used in the hydrophytic systems of wastewater treatment but its best use is for the purpose of after-treatment of municipal wastewater.
\end{abstract}

Key words: surface water quality, phytoremediation, heavy metals, metal removal efficiency, biogenic compounds, Hippuris vulgaris.

\section{INTRODUCTION}

Despite increased environmental awareness, the level and effects of surface and groundwater pollution are still noticeable. The sources of biogenic compounds and metals entering waters are: industry, agricultural activities and sewage from industrial and municipal wastewater plants. These pollutants have a negative effect on usability of water reservoirs

Corresponding author: Małgorzata Gałczyńska, Department of Chemistry, Microbiology and Biotechnology of Environment, West Pomeranian University of Technology, Szczecin, Juliusza Słowackiego 17, 71-434 Szczecin, Poland, e-mail: Malgorzata.Galczynska@zut.edu.pl 
and may result in degradation of aquatic ecosystems. The aim of the Water Framework Directive was to achieve "good" water status till 2015. Out of the various elements, biological indices play a major role in assessing the quality of aquatic ecosystems, among others, by macrophytes. The species composition and the number of plants provide information on the level of eutrophication of waters. Moreover, aquatic plants are known to accumulate metals in large amounts and therefore can indicate the level of water contamination with toxic metals. Additionally, macrophytes are used in establishing constructed hydrophyte wetlands as they cooperate with microorganisms in treatment of municipal wastewater and clean of treated wastewater and rainwater (Vymazal 2013).

Nowadays, numerous technological solutions are available for purification of waters to the level indicated in legislation. However, limitations and possibilities of phytoremediation, known to be less adverse and more economic method, are also being considered (Bello et al. 2018). Phytoremediation is a biological method of treatment and detoxification of environment with the use of plants. It is based on initiating the three types of physiological response of plants to contamination present in the environment - exclusion, accumulation and hyper-accumulation. The plants used in this method should be characterised by tolerance to high concentration of xenobiotics, high level of accumulation or biodegradation of contaminants, significant efficiency of concurrent accumulation of several contaminants, enhanced growth and significant production of biomass, resistance to diseases, pests and variable environmental conditions (Marecik et al. 2006; Ali et al. 2013). Phytoremediation mechanisms are distinguished by the fact that plants affect the purification of contaminated ecosystems (Fig. 1).

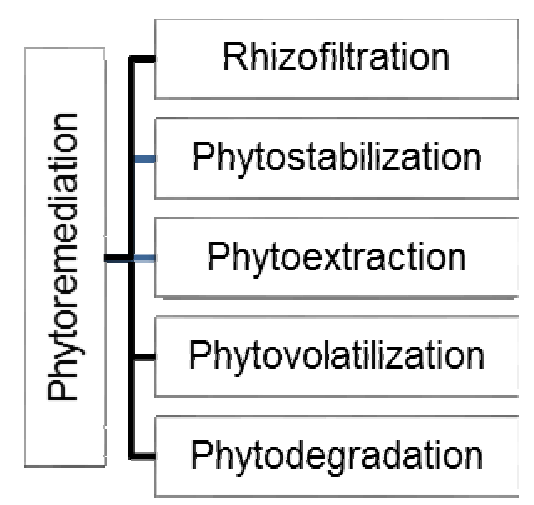

Fig. 1. Phytoremediation mechanisms depending on the scale of pollution

Rhizofiltration means that plants are used to absorb, concentrate, and precipitate contaminants from polluted aquatic environment by their roots. The species mainly used in this method are Phragmites australis Cav. Trin. ex Steud., Typha latifolia L. and Lemna minor L. Phytostabilization involves the stabilization of contaminated soils by sorption, precipitation, complexation, or metal valence reduction rather than the removal of contaminants. Phytoextraction, also referred to as phytoaccumulation, is the process in which plants absorb, concentrate, and precipitate the contaminants in the biomass. Phytovolatilization is the mechanism of plants extracting certain contaminants in nearby roots and then transpiring them into the atmosphere. Phytodegradation consists in plants removing 
contaminants from environment by their metabolism. It is assumed that there are dozens of plant species growing in Poland which could potentially be used in hydrophyte treatment of municipal and industrial wastewater, as well as for treatment of contaminated waters, including rainwater. The biological features which predispose these plants to such purpose are e.g. high biomass growth rate, resistance to variable concentration of biogenic compounds in water and accumulation of toxic metals.

The purpose of this review is to discuss the biological features of Hippuris vulgaris L. and characterize its occurrence, determine the ability of the plant to develop in waters contaminated with biogenic compounds and metals, and determine the plant's ability to collect metals measured by the effectiveness of removing contaminants.

\section{BIOLOGICAL CHARACTERISTICS OF COMMON MARE'S TAIL}

Common mare's tail has a single, straight, tubular and densely leaved stalk, the colour of which is markedly lighter than the colour of the leaves. The leaves are ensiform, elongated, simple, blunt, dark green in colour and occur in whorls of 8-12. Specific leaf area of common mare's tail is $73.7 \pm 5.84 \mathrm{~mm}^{2} \mathrm{mg}^{-1}$ (Pierce et al. 2012). The leaves differ in turgidity and shape depending on the environment. The above-water leaves are rigid, whereas the underwater leaves are soft, longer and bent downwards (Fig. 2). Dry mass content of leaves is $12.5 \pm 0.88 \%$ (Pierce et al. 2012). The flowers which develop in the corners of the above-water leaves in July are fine, sessile, greenish, anemophilous and hermaphroditic. The fruits are ovoid drupes of $2 \mathrm{~mm}$ in length and $1 \mathrm{~mm}$ in thickness. They fall into the mud bottom and are characterised by high variation in terms of plant propagation. Due to small size of the drupe, it can spread through wind, i.e. anemochorically, through the water surroundings hydrochorically, and by birds feeding on the sweet seeds of the plant - ornitochorial seed dispersion. The perennial can spread laterally to approx. $45 \mathrm{~cm}$, however the size depends on the depth of the water: in the coastal zone it can grow to $30 \mathrm{~cm}$ and in midwater the shoot can reach $2 \mathrm{~m}$ in length (Podbielkowski and Tomaszewicz 1996).

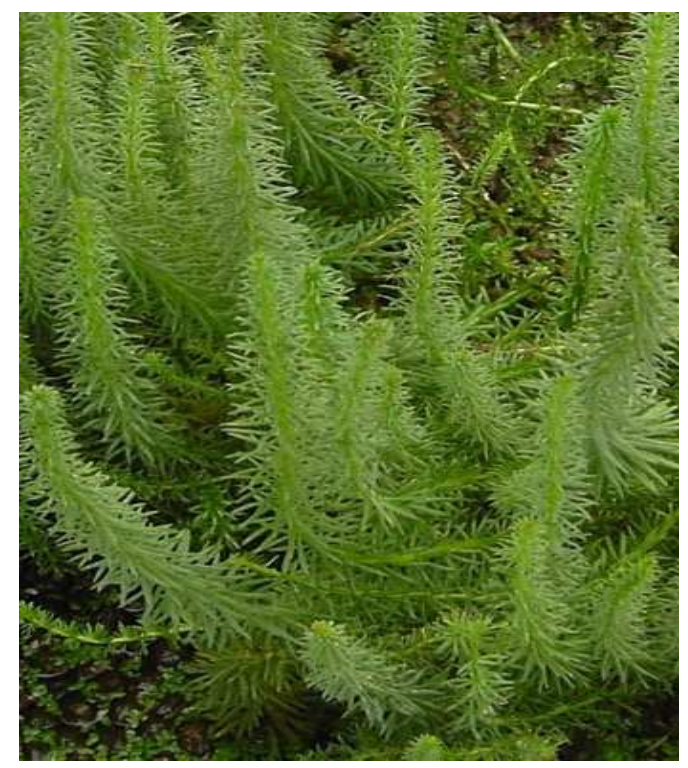

Fig. 2. Hippuris vulgaris L. grown in wastewater treated (photo: M. Gałczyńska) 


\section{CHARACTERISTICS OF COMMON MARE'S TAIL HABITAT}

Common mare's tail is a creeping perennial herb found in waters, semi-aquatic or land habitats. In the terrestrial and semi-aquatic forms, the shoots die in winter, and the underwater part survives the winter form is evergreen (Greulich and Bornette 2002). The plant inhabits meso- and eutrophic standing or flowing water reservoirs as well as wet meadows (Podbielkowski and Tomaszewicz 1996; Venterink et al. 1998; Hatton-Ellis and Grieve 2003; Nurminen 2003; Gałczyńska 2006; Stovall 2007). It prefers sandy-loamy and peat soils nearby the shores of water reservoirs right from the early stages of development till the final developmental stage. The plant is particularly abundant in alkali waters rich in calcium compounds (Podbielkowski and Tomaszewicz 1996). Sunny or slightly shaded location is favoured by the plant (Buczacki 1997). Moderately cool or moderately warm climatic conditions constitute the thermal index of the plant. Hippuris vulgaris is characterised by wide distribution: from the arctic waters in Greenland and Alaska (Au et al. 2017), through temperate latitudes (Öztürk et al. 2015; Ouyang et al. 2016) in Australia to the southern areas of North America where the plant is described as an indigenous species (Fernandez-Alaez et al. 1999; Nurminen 2003; Xiang et al. 2009; Gao et al. 2011). In Poland it is found mainly in lowlands, less often in lower mountainous regions. Common mare's tail is a frost hardy plant - it survives the coldest winters even at $-20^{\circ} \mathrm{C}$. It propagates vegetatively through stolons and buds, the latter of which also serve the purpose of overwintering (Bernatowicz and Wolny 1969; Podbielkowski and Tomaszewicz 1996; Buczacki 1997; Rutkowski 2004).

Hippuris vulgaris is characterised by significant capacity for development in variable trophic conditions, including municipal wastewater where oxygenation properties of the plant are particularly favoured (Gałczyńska 2012; Huang et al. 2012; Gałczyńska et al. 2013; Choudhury et al. 2018). It is able to adapt to different rates of water flow. In small standing water reservoirs it prevails in eutrophic waters of elevated calcium content, and the increase in population is observed in waters with elevated nitrates(V) content (Gałczyńska 2006). The percentage content of nitrogen and carbon in leaves of common mare's plant is $3.4 \pm 0.03$ and $38.2 \pm 0.13$ (Pierce et al. 2012), respectively. The plant shows the ability to colonise the areas which are continuously being flooded (Barrat et al. 1998). Additionally, in environment contaminated with e.g. insecticide, common mare's tail can regenerate unless the rhizomes or roots were damaged (Gałczyńska et al. 2016). This is one of the aquatic plants which reflect water contamination levels through its ability to accumulate heavy metals (Bayindir and Ikinci 2012; Gałczyńska 2012; Gałczyńska et al. 2013). Most frequently, the metals are accumulated in roots and shoots and accumulation rate is determined by the type and content of a given element in water (Fritioff 2005; Gałczyńska 2012).

\section{THE USE OF HIPPURIS VULAGRIS IN THE ASSESSMENT OF WATER STATUS}

Hippuris vulgaris is one of the 45 species of hydrophytes used in calculating macrophytic index in ecological assessment of lakes (Melzer 1999). The indicator values of common mare's tail are: $L=4$ and $W=1$, which shows that the plant prefers habitats of moderate eutrophication level, however the plant also demonstrates varying degree of tolerance to nitrogen and phosphorus compounds in water. The plant is used for the purpose of 
assessment of ecological status of standing and flowing waters in many European countries (the Mean Trophic Rank - MTR in United Kingdom, the Trophic Index of Macrophytes - TIM in Germany, the Ecological State Macrophyte Index - ESMI in Poland, Macrophyte River Index - MRI in Poland) (Szoszkiewicz et al. 2002; Dawson et al. 1999; Holmes et al. 1999; Schneider and Melzer 2003; Schneider 2007).

Hippuris vulgaris inhabits waters contaminated with metals. The presence of this plant was confirmed in waters with iron concentration from 0.010 to $1.28 \mu \mathrm{g} \cdot \mathrm{dm}^{-3}$ (Goszczyński and Szatten 2010; Krajewski 2000), manganese 0.007-302 $\mu \mathrm{g} \cdot \mathrm{dm}^{-3}$ (Scholz and Anderson 2003; Wiechuła et al. 2004), zinc 5.8-80 $\mu \mathrm{g} \cdot \mathrm{dm}^{-3}$ (Trawczyńska et al. 2009), copper 1.00-140 $\mu \mathrm{g} \cdot \mathrm{dm}^{-3}$ (Trawczyńska et al. 2009), lead 1.00-320 $\mu \mathrm{g} \cdot \mathrm{dm}^{-3}$ (Trawczyńska et al. 2009; Szczepańska and Szpakowska 2009).

The plant participates in removing various metals from the aquatic environment, e.g.: copper, cadmium, chromium, nickel, lead and zinc (Akson and Visoottiviseth 2004). Uptake and accumulation of metals from water depends on the concentration of biogenic compounds (PNK) : (Fe 3.28, 3.30; $3.21 \mathrm{mg} \cdot \mathrm{g}^{-1}$ d.w., Mn 567, 545; $473 \mu \mathrm{g} \cdot \mathrm{g}^{-1}$ d.w., Zn 216, 348; $421 \mu \mathrm{g} \cdot \mathrm{g}^{-1}$ d.w., Cu 34.1, 49.9; $53.3 \mu \mathrm{g} \cdot \mathrm{g}^{-1}$ d.w., Pb 55.9, 57.4; $56.0 \mu \mathrm{g} \cdot \mathrm{g}^{-1}$ d.w. and (PNK) 2 : (Fe 3.88, 3.42; $3.09 \mathrm{mg} \cdot \mathrm{g}^{-1}$ d.w., Mn 585, 528; $397 \mu \mathrm{g} \cdot \mathrm{g}^{-1}$ d.w., Zn 268, 362; $400 \mu \mathrm{g} \cdot \mathrm{g}^{-1}$ d.w., Cu 30.3, 48.1; $48.9 \mu \mathrm{g} \cdot \mathrm{g}^{-1}$ d.w., Pb 64.1, 56.4; $47.3 \mu \mathrm{g} \cdot \mathrm{g}^{-1} \mathrm{~d} . \mathrm{w}$. and the number of doses of a given metal salts (Gałczyńska 2012) - Fig. 3-7.

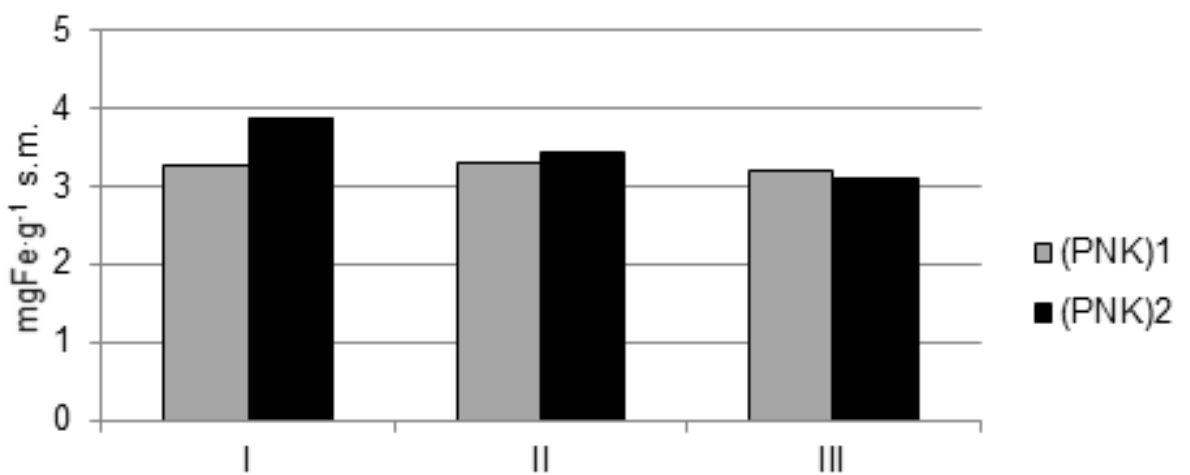

Number of doses

Fig. 3. Fe content in Hippuris vulgaris

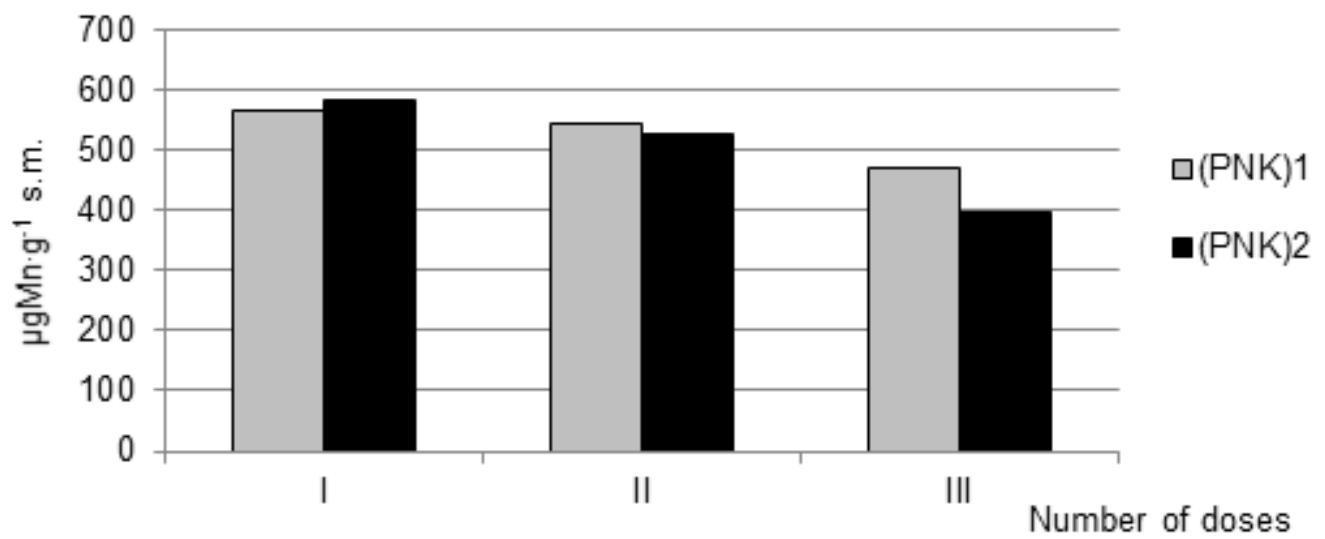

Fig. 4. Mn content in Hippuris vulgaris 


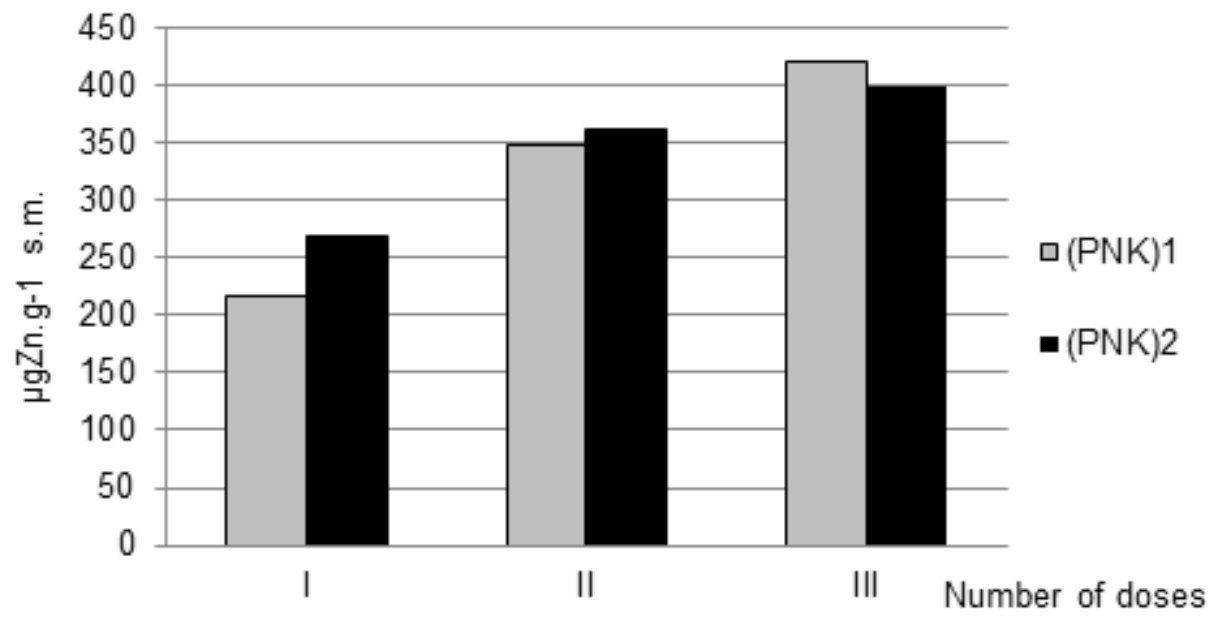

Fig. 5. Zn content in Hippuris vulgaris

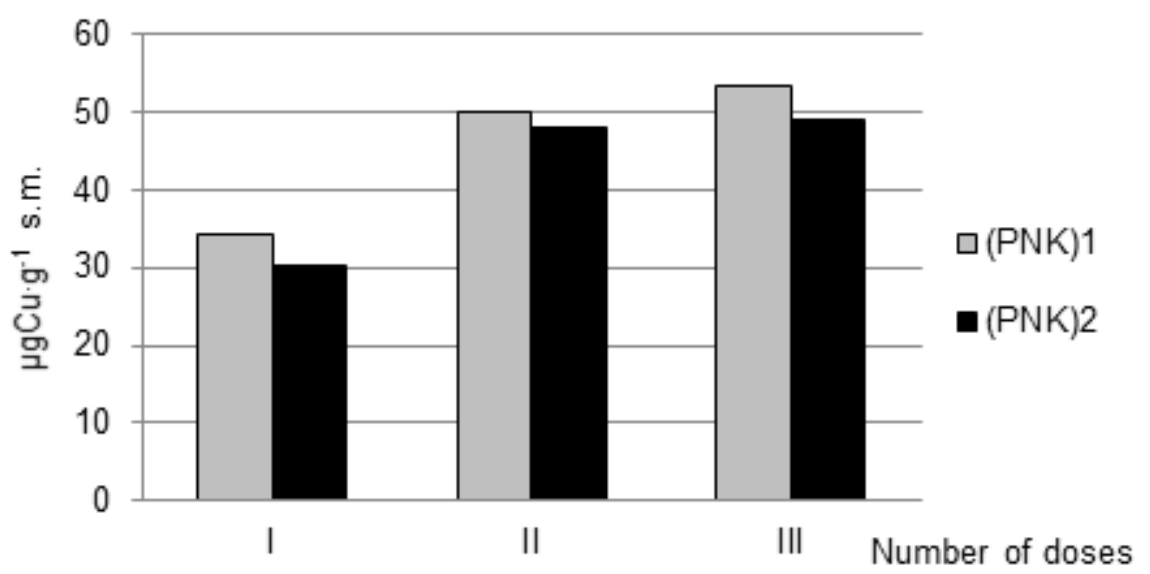

Fig. 6. Cu content in Hippuris vulgaris

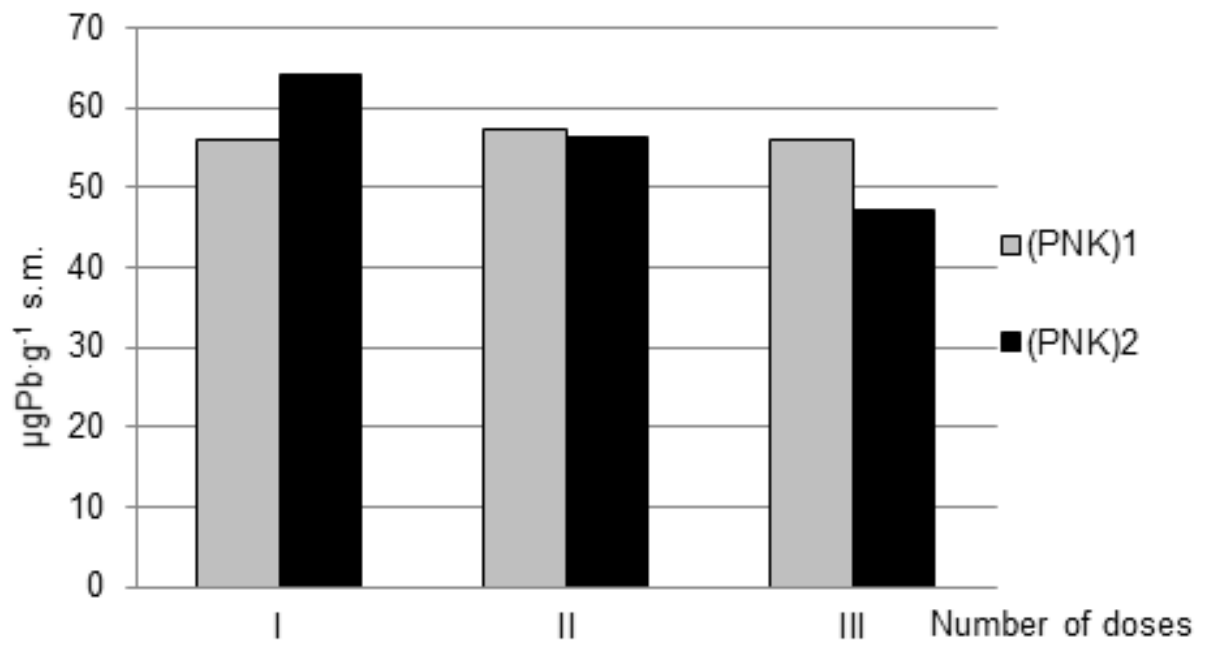

Fig. 7. Pb content in Hippuris vulgaris 


\section{THE USE OF HIPPURIS VULGARIS IN PURIFICATION OF METAL CONTAMINATED WATER}

The uptake of metals affects the development of Hippuris vulgaris. The decrease in biomass of the plant was observed in water contaminated with one of the following metals: lead $\left(0.6 \mathrm{mg} \cdot \mathrm{dm}^{-3}\right)$, zinc $\left(2.4 \mathrm{mg} \cdot \mathrm{dm}^{-3}\right)$, manganese $\left(1.2 \mathrm{mg} \cdot \mathrm{dm}^{-3}\right)$ and iron $\left(2.4 \mathrm{mg} \cdot \mathrm{dm}^{-3}\right)$. This points to limitations of use of this plant for the purpose of purifying waters heavily contaminated with metals. The fact is also confirmed by the efficiency of metal accumulation index $\left(E_{p}\right)$. Mean value of the index for selected metals is the following: Fe from 4.2 to $104.2 \%$, Mn from 10.4 to $37.9 \%$, Zn from 15.6 to $29.2 \%$, Cu from 0.8 to $34.2 \%$, and Pb from 0.3 to $6.7 \%$ (Gałczyńska 2012 ).

\section{THE USE OF HIPPURIS VULGARIS IN PURIFICATION OF USED WATERS}

Nonorganic water contaminants are removed by aquatic plants mainly by means of the following mechanisms: rhizofiltration, phytostabilisation and phytoextraction (Kanwa and Shad 2018). In freshwater systems, macrophytes, including vascular plants and aquatic moss, are the key autotroph plants which facilitate ecosystem activities related to removing nutrients and water purification. One of the key functions of macrophytes in constructed hydrophyte wetlands is providing favourable oxidation-reduction conditions for mineralisation of organic matter by microorganism around rhizomes and roots and, to a lesser degree, uptake of dissolved nitrogen (N) and phosphorus (P) (Vymazal 2013), and the following assimilation of these nutrients to the macrophyte biomass. The efficacy of hydrophyte wastewater treatment systems is evaluated by reduction of concentration of the five parameters: $\mathrm{BOD}_{5}, \mathrm{COD}$, general nitrogen, general phosphorus, general slurry. The study by Gałczyńska (2012) provides an assessment of the efficacy of eliminating contaminants from municipal treated and raw wastewater in constructed wetlands based on cultivation of Hippuris vulgaris. The author determined that depending on the time of treated wastewater retention (Fig. 8), and in the case of raw wastewater also depending on the time of retention, the reduction of the analysed parameters was lower and amounted to: $\mathrm{BOD}_{5}$ ranged from 20 to $88 \%$; COD from 39 to $76 \%$, total nitrogen (TN) from 84 to $94 \%$ total phosphorus (TP) from 67 to $94 \%$, and total slurry from 14 to $94 \%$ after 3 weeks, and reduction BOD $_{5}$ from 60 to $72 \%$; COD from 52 to $67 \%$; TN from 85 to $95 \%$; TP from 73 to $96 \%$, for total slurry from 60 to $79 \%$ after 6 weeks, and after 9 weeks, reduction $\mathrm{BOD}_{5}$ from 78 to $100 \%$; COD from 24 to $65 \%$; TN from 89 to $96 \%$; TP from 93 to $96 \%$ for total slurry from 77 to $80 \%$. In the case of raw sewage (Fig. 9), also depending on the time of their stopping, the reduction of the analyzed parameters was lower and amounted to: $\mathrm{BOD}_{5}$ ranged from 95 to $98 \%$; COD from 79 to $95 \%$; TN from 93 to $95 \%$; TP from 89 to $90 \%$; for total slurry from 96 to $98 \%$.

In turn, Choudhury et al. (2018) found that in hydrophyte systems based on two aquatic species, one of them being Hippuris vulgaris, the efficacy of nitrogen removal was from 2 to $6 \%$ higher than that observed in single species systems with Hippuris vulgaris - on average $89 \%$. The results obtained by Gałczyńska (2012) and Choudhury et al. (2018) indicate the suitability of use of Hippuris vulgaris in hydrophyte systems for nitrogen removal from used waters. The efficacy of contaminants removal for nitrogen was, on average, $94.1 \%$ 
(Gałczyńska 2012) and $85 \%$ in single species systems including Hippuris vulgaris (Choudhury et al. 2018). Gałczyńska et al. (2009) found that with the decrease in growth rate of the plant in the autumn period, the efficacy of removing contaminants from wastewater decreases.

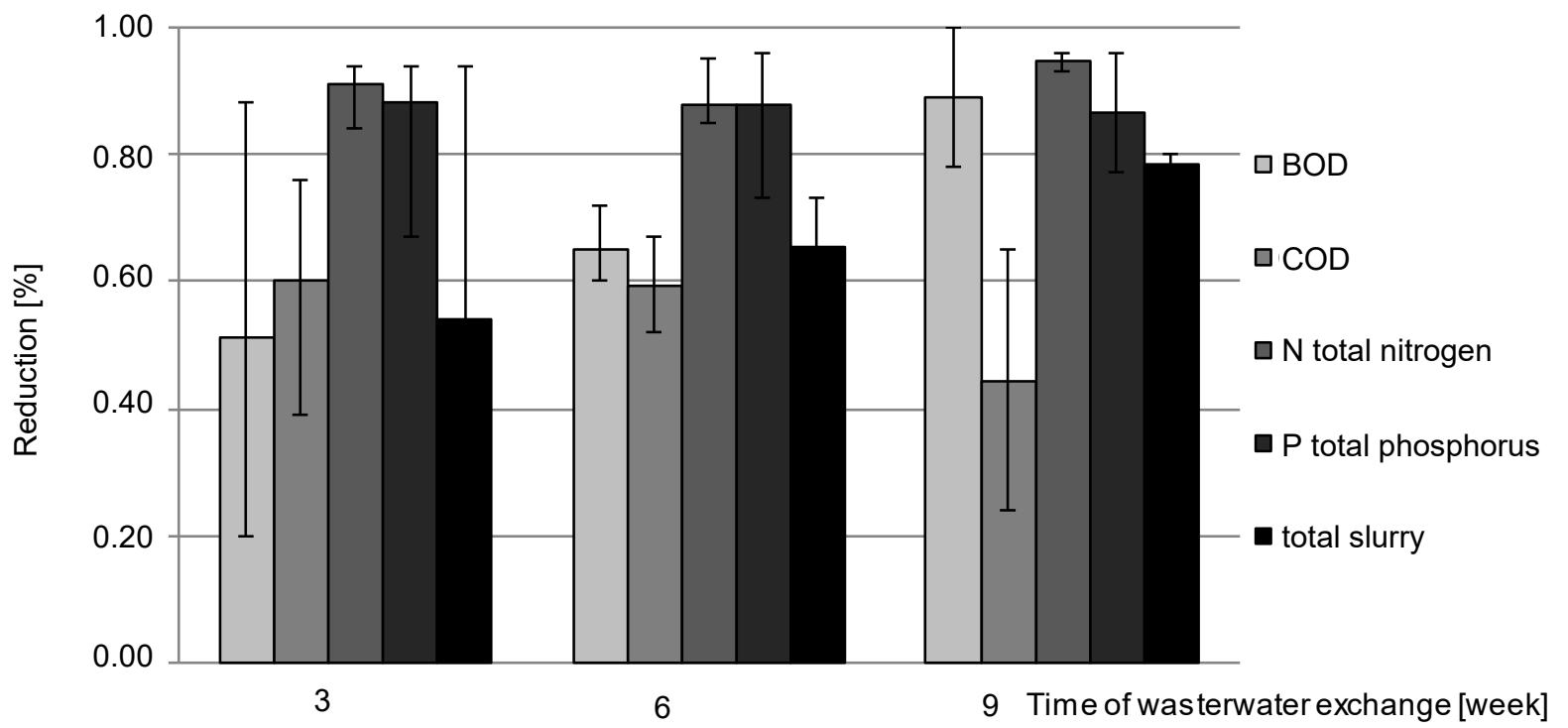

Fig. 8. Effectiveness of removing pollutants from treated wastewater

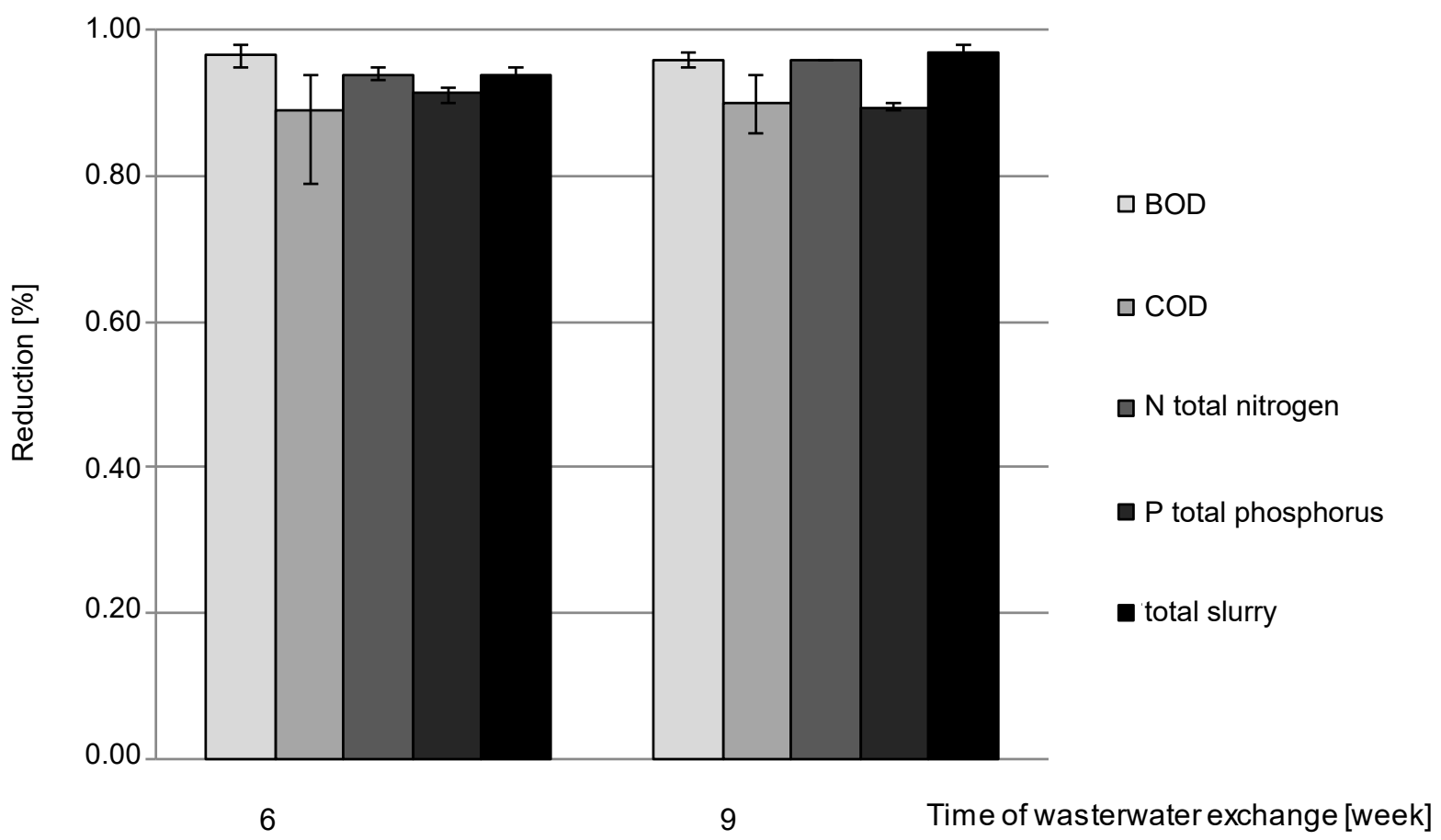

Fig. 9. Effectiveness of removing pollutants from raw wastewater 


\section{REMOVAL OF METALS FROM USED WATERS}

Low efficacy of metal uptake by Hippuris vulgaris from solutions contaminated with metals does not exclude the use of this plant in hydrophyte systems. The studies conducted on treated wastewater show that the highest concentration of metal in dry weight yield of common mare's tail was found for iron in all periods under analysis, and the lowest concentration was determined for lead - also in all analysed periods (Table 1). As for raw municipal wastewater (Table 2), the highest concentration of iron was found in week 6 as well as week 9 of the observation, and the lowest concentration was determined for lead.

Table 1. Average content of metals in the dry matter yield of Hippuris vulgaris in facilities with municipal wastewater

\begin{tabular}{lccccc}
\hline Experiment duration & $\mathrm{Pb}$ & $\mathrm{Cu}$ & $\begin{array}{c}\mathrm{Zn} \\
{[\mathrm{mg} \mathrm{d.w.}]}\end{array}$ & $\mathrm{Mn}$ & $\mathrm{Fe}$ \\
\hline 3 weeks & & & 38.63 & 210.9 & 231.8 \\
\hline 6 weeks & 0.533 & 5.597 & 39.80 & 90.90 & 216.7 \\
\hline 9 weeks & 0.559 & 5.514 & 18.65 & 38.14 & 78.82 \\
\hline
\end{tabular}

Table 2. Average content of metals in the dry matter yield of Hippuris vulgaris in facilities with municipal raw sewage

\begin{tabular}{lcclcr}
\hline Experiment duration & $\mathrm{Pb}$ & $\mathrm{Cu}$ & $\begin{array}{l}\mathrm{Zn} \\
{[\mathrm{mg} \mathrm{d.w.}]}\end{array}$ & $\mathrm{Mn}$ & $\mathrm{Fe}$ \\
\hline 6 weeks & 0.032 & 0.240 & 1.414 & 14.09 & 17.45 \\
\hline 9 weeks & 0.395 & 2.576 & 18.95 & 46.30 & 115.40 \\
\hline
\end{tabular}

The design of hydrophyte system with Hippuris vulgaris and wastewater replacement time affects metal uptake by the plant (Gałczyńska 2012 and Gałczyńska et al. 2013). In the case where soil substrate was used, the amount of uptaken zinc was $498 \mathrm{mg} \cdot \mathrm{kg}^{-1} \mathrm{~d}$.w., manganese $439 \mathrm{mg} \cdot \mathrm{kg}^{-1}$ d.w., and copper $0.55 \mathrm{mg} \cdot \mathrm{kg}^{-1} \mathrm{~d}$.w. When the plant was cultivated on LECA bed, the uptake of the aforementioned elements by the plant was different (Cu $15 \mathrm{mg} \cdot \mathrm{kg}^{-1} \mathrm{~d} . \mathrm{w}$., Mn $920 \mathrm{mg} \cdot \mathrm{kg}^{-1}$ d.w., Zn $92 \mathrm{mg} \cdot \mathrm{kg}^{-1} \mathrm{~d} . \mathrm{w}$.). However, both experiments showed some differences in terms of wastewater replacement time (system with soil substrate - on average 9 weeks, LECA bed -7.5 weeks). The differences in accumulation of the metals in question may be due to varied access to mineral nutrients (Gałczyńska 2012) in both systems and the presence of different groups of microorganisms (Wężowicz et al. 2015) facilitating defence mechanisms of metal uptake in the soil substrate system by the root system.

\section{SUMMARY}

Common mare's tail grows in waters with variable concentration of biogenic compounds and metals. Regardless of the concentration of nitrogen, phosphorus and potassium in the growth environment of the plant, each introduction of nitrogen, zinc, copper, manganese and iron in the amount equivalent to limit concentration for class $V$ of water quality pursuant to the Regulation of the Minister of Environment of 2004, resulted in an increased uptake by the 
plant. Accumulation of these elements reflects the level of contamination of water with metals. However, water contamination with particular metals ( $\mathrm{Zn}, \mathrm{Mn}, \mathrm{Pb}$ or $\mathrm{Fe}$ ) results in decreased biomass of the plant. Common mare's tail can be used in hydrophyte municipal wastewater treatment systems due to its high efficacy of removing various contaminants, however the best use is thorough cleaning of treated municipal sewage.

\section{REFERENCES}

Akson E., Visoottiviseth P. 2004. Selection of suitable emergent plants for removal of arsenic from arsenic contaminated water. Sci. As. 30, 105-113.

Ali H., Khan E., Sajad M.A. 2013. Phytoremediation of heavy metals - concepts and applications. Chemosphere 91, 869-881.

Au N.T., Ryman T., Rettie A.E., Hopkins S.E., Boyer B.B., Black J., Philip J., Yracheta J., Fohner A.E., Reyes M., Thornton T.A., Austin M.A., Thummel K.E. 2017. Dietary vitamin K and association with hepatic vitamin $\mathrm{K}$ status in a Yup'ik study population from Southwestern Alaska. Mol. Nutr. Food Res. 62(3), 1700746.

Barrat M., Bornette G., Hering A. 1998. Comparative abilities of vegetative regeneration among aquatic plants growing in disturbed habitats. Aquat. Bot. 60(3), 201-211.

Bayindir N., Ikinci N. 2012. Aquatic macrophyte diversity of Yumrukaya wetland and Lake Golkoy, in: International Symposium on Aquatic Plants. Poznań, Poland, August 27-31, 2012, Poznań University of Life Sciences.

Bello A.O., Tawabini B.S., Khalil A.B., Boland C.R., Saleh T.A. 2018. Phytoremediation of cadmium, lead and nickel contaminated water by Phragmites australis in hydroponic systems. Ecol. Eng. 120, 126-133.

Bernatowicz S., Wolny P. 1969. Botanika rybacka. Warszawa, PWRiL. [in Polish]

Buczacki S. 1997. Rośliny wodne. Warszawa, Wydaw. Elipsa. [in Polish]

Choudhury M.I., McKie B.G., Hallin S., Ecke F. 2018. Mixtures of macrophyte growth forms promote nitrogen cycling in wetlands. Sci. Total Environ. 635, 1436-1443.

Dawson F.H., Newman J.R., Gravelle M.J. 1999. Assessment of the trophic status of rivers using macrophytes: Evaluation of the Mean Trophic Rank. R \& D Techn. Report E39. London, Environment Agency.

Fernandez-Alaez M., Fernandez-Alaez C., Rodriguez S., Becares E.1999. Evaluation of the state of conservation of shallow lakes in the Province of Leon (Northwest Spain). Using Bot. Criteria, Limnetica 17, 107-117.

Fritioff A. 2005. Metal accumulation by plants evaluation of the use of plants in stormwater treatment. $\mathrm{PhD}$ thesis. Plant Physiology Department of Botany Stockholm University Sweden (unpublished).

Gałczyńska M. 2006. Impact of chemical properties of water in small reservoirs on development of Hippuris vulgaris. Sites. Polish J. Environ. Stud. 15(5d), 567-570.

Gałczyńska M., Iżewska A., Małas A. 2009. Oddziaływanie przęstki pospolitej (Hippuris vulgaris) na redukcję stężeń azotu i fosforu w oczyszczanych roztworach ze ścieku i osadu komunalnego [Influence of Hippuris vulgaris L. on the reduction of nitrogen and phosphorus concentrations in cleaned solutions of municipal sewage and sewage sludge]. Zesz. Probl. Post. Nauk Rol. 537, 105-113. [in Polish]

Gałczyńska M. 2012. Reakcja przęstki pospolitej (Hippuris vulgaris L.) i żabiścieku pływającego (Hydrocharis morsus-ranae L.) na zanieczyszczenie wody wybranymi metalami ciężkimi i możliwości wykorzystania tych roślin w fitoremediacji wód [Response of the mare's tail (Hippuris vulgaris L.) and frogbit (Hydrocharis morsusranae L.) to water pollution with heavy metals and a possibility of using these plants for water phytoremediation]. Szczecin, Wydaw. Uczelniane ZUT. ISBN 8376631373. [in Polish] 
Gałczyńska M., Gibczyńska M., Michalcewicz W., Małas A. 2013. Uptake of manganese, zinc and copper by Hippuris vulgaris L. from wastewater solutions and soil substrate polluted with sewage sludge. Zesz. Nauk. UP Wroc., Ser. Rolnictwo 106(595), 45-58.

Gałczyńska M., Swarcewicz M., Paździoch W. 2016. Assessment of the impact of Decis 2.5 EC on the growth of Hippuris vulgaris. CLEAN - Soil. Air. Water 44(10),1329-1334.

Gao L., Tang Y., Bossard C., Wang Y., Han Z. 2011. Diurnal variation in relative photosynthetic performance of marestail (Hippuris Vulgaris Linn.) Across a water temperature gradient using PAM fluorometry in Jiuzhaigou National Nature Reserve, Sichuan Province, China. J. Mt. Sci. 8, 794807.

Goszczyński J., Szatten D. 2010. Jezioro Gopło. Bydgoszcz, Wydz. Monit. Środ. WIOŚ. [in Polish]

Greulich S., Bornette G. 2002. Being evergreen in an aquatic habitat with attenuated seasonal contrasts - a major competitive advantage. Plant Ecol. 167, 9-18.

Huang Y-C., Tian K., Yue H-T., Ge X-X. 2012. Study on purification effect of four Yunnan Plateau aquatic plant communities on TP and COD in the domestic sewage. Yunnan Forest Sci. Technol. 2, 33-37.

Hatton-Ellis T.W., Grieve N. 2003. Ecology of watercourses characterised by Ranunculion fluitantis and Callitricho-Batrachion vegetation conserving Natura 2000 Rivers. Life in UK Rivers Peterborough, Ecol. Ser. 11.

Holmes N.T.H., Newman J.R., Chadd S., Rouen K.J., Saint L., Dawson F.H. 1999. Mean trophic Rank. A user's Manual, R \& D Technical Report No. E38. Bristol, UK, Environment Agency.

Kanwa Q., Shad S. 2018. Aspects of xenobiotics phytoremediation and role of endophytic bacteria and arbuscular mycorrhizal association. J. Plant. Biol. Crop. Res. 2,1007.

Krajewski Z. 2000. Raport o stanie środowiska województwa kujawsko-pomorskiego w 1999 roku. Bydgoszcz, WIOŚ. [in Polish]

Marecik R., Króliczak P., Cyplik P. 2006. Fitoremediacja - alternatywa dla tradycyjnych metod oczyszczania środowiska [Phytoremediation - an alternative to traditional methods of environmental cleansing]. Biotechnologia 3, 88-97. [in Polish]

Melzer A. 1999. Aquatic macrophytes as tools for lake management. Hydrobiologia 395/396, 181-190.

Nurminen L. 2003. Macrophyte species composition reflecting water quality changes inadjacent water bodies of Lake Hiidenvesi, SW Finland. Ann. Bot. Fenn. 40, 199-208.

Ouyang L., Pan Y., Huang C., Tang Y., Du J., Xiao W. 2016. Water quality assessment of benthic diatom communities for water quality in the subalpine karstic lakes of Jiuzhaigou, a world heritage site in China. J. Mt. Sci. 13(9), 1632-1644.

Öztürk M., Tatlı A., Özçelik H., Behçet L. 2015. General characteristics of flora and vegetation formations of Eastern Anatolia Region and its environs (Turkey). Süleyman Demirel Univ. J. Sci. 10, 23-48.

Pierce S., Brusa G., Sartori M., Cerabolini B.E. 2012. Combined use of leaf size and economics traits allows direct comparison of hydrophyte and terrestrial herbaceous adaptive strategies. Ann. Bot. 109, 1047-1053.

Podbielkowski Z., Tomaszewicz H. 1996. Zarys hydrobotaniki. Warszawa, PWN. [in Polish]

Rutkowski L. 2004. Klucz do oznaczania roślin naczyniowych Polski niżowej. Warszawa, Wydaw. Nauk. PWN. [in Polish]

Schneider S. 2007. Macrophyte trophic indicator values from a European perspective. Limnologica 37, 281-289.

Schneider S., Melzer A. 2003. The Trophic Index of Macrophytes (TIM) a new tool for indicating the trophic state of running waters. Int. Rev. Hydrobiol. 88, 49-67.

Scholz M., Anderson P. 2003. Design, operation and water quality management of a combined wet and dry pond system. Official publication of the European Water Association (EWA), 1-18, http://www.ewaonline.de/journal/2003_071.pdf, access: 10.01.2011. 
Stovall H. 2007. Natural alternatives to conventional wastewater treatment, http://lda.ucdavis.edu/ /people/2007/HStovall.pdf, access: 10.01.2011.

Szoszkiewicz K., Karolewicz K., Ławniczak A., Dawson F.H. 2002. An assessment of the MTR aquatic plant bioindication system for determining the trophic status of polish rivers. Pol. J. Environ. Stud. 11(4), 421-427.

Szczepańska M., Szpakowska B. 2009. Rekreacyjne znaczenie Zbiornika Maltańskiego i problemy związane z jego użytkowaniem [Recreational aspects of the Maltański Reservoir and problems of its usage]. Nauka Przyr. Technol. 3(1), 1-10. [in Polish]

Trawczyńska A., Tołoczko W., Niewiadomski A. 2009. Zawartość pierwiastków śladowych w wodach górnej Bzury [The content of trace elements in the Bzura waters]. Ochr. Środ. Zas. Natur. 40, 491-496. [in Polish]

Vymazal J. 2013. Emergent plants used in free water surface constructed wetlands. A review. Ecol. Eng. 61, 582-592.

Venterink H.O., Pieterse N.M., Wassen M.J., Verkroost A.W.M. 1998. Demonstration project for the Development of Integrated Management Plans for Catchment Areas of Small Trans-Border Lowland Rivers: the River Dommel. Utrecht, http://mk.geog.uu.nl/products/reports/ecostream.pdf, access: 10.01.2011.

Wężowicz K., Turnau K., Anielska T., Zhebrak I., Gołuszka K., Błaszkowski J., Rozpądek P. 2015. Metal toxicity differently affects the Iris pseudacorus-arbuscular mycorrhiza fungi symbiosis in terrestrial and semi-aquatic habitats. Environ Sci. Pollut. Res. 22, 19400.

Wiechuła D., Loska K., Korus I. 2004. Wpływ warunków tlenowych i odczynu na zawartość manganu w wodzie Zbiornika Rybnickiego [The influence of aerobic conditions and the reaction on the content of manganese in the water of Rybnik Reservoir]. Rocz. PZH 55(Supl.), 185-190. [in Polish]

Xiang S.A., Guo R.Q., Wu N., Sun S.C. 2009. Current status and future prospects of Zoige Marsh in Eastern Qinghai-Tibet Plateau. Ecol. Eng. 35, 553-562.

\section{PRZĘSTKA POSPOLITA (Hippuris vulgaris L.) W OCENIE STANU WÓD I ICH FITOREMEDIACJI}

Streszczenie. Zanieczyszczenie ekosystemów wodnych nadal stanowi problem w krajach rozwiniętych, powodując zmniejszenie bioróżnorodności organizmów związanych z tymi siedliskami. W wielu krajach $w$ ocenie zanieczyszczenia wód powierzchniowych stosuje się indeksy makrofitowe. Są one stosowane zarówno do określania stanu ekologicznego jezior, jak i rzek. Obecność roślin wodnych informuje m.in. o poziomie eutrofizacji wód, a analiza zawartości metali w roślinach wskazuje na zanieczyszczenie metalami ekosystemów wodnych. Nieosiągnięcie w 2015 roku kluczowego celu ramowej dyrektywy wodnej, tj. dobrego stanu wód, wymusza poszukiwanie nowych sposobów zarządzania wodami, w tym tanich i przyjaznych środowisku metod oczyszczania wód zanieczyszczonych i zużytych. Wyniki badań dotyczące możliwości i ograniczeń funkcjonowania poszczególnych gatunków roślin wodnych w zanieczyszczonych i zużytych wodach pozwalają na racjonalny dobór roślin do fitoremediacji ekosystemów wodnych. Celem niniejszej pracy przeglądowej było omówienie cech biologicznych przęstki pospolitej i scharakteryzowanie środowiska jej występowania, określenie zdolności rozwoju tej rośliny w wodach zanieczyszczonych związkami biogennymi i metalami oraz ustalenie jej możliwości do pobierania metali, mierzonej skutecznością usuwania zanieczyszczeń. Stwierdzono, że przęstka pospolita występuje w wodach o zmiennym stężeniu związków biogennych i metali. Niezależnie od stężenia azotu, fosforu i potasu w środowisku wzrostu rośliny każdorazowe wprowadzenie do niego ołowiu, cynku, miedzi, manganu i żelaza, w ilościach odpowiadających stężeniom granicznym dla $\mathrm{V}$ klasy jakości wód, powoduje zwiększone ich pobieranie przez przęstkę pospolitą. Akumulacja tych pierwiastków odzwierciedla stan zanieczyszczenia wód metalami. Niemniej jednak zanieczyszczenie wód niektórymi metalami 
powoduje zmniejszenie biomasy rośliny. Przęstka pospolita może być stosowana $w$ hydrofitowych systemach oczyszczania ścieków komunalnych z uwagi na wysoką skuteczność usuwania z nich różnych zanieczyszczeń, ale najlepszym jej zastosowaniem jest doczyszczanie oczyszczonych ścieków komunalnych.

Słowa kluczowe: jakość wód powierzchniowych, fitoremediacja, metale ciężkie, skuteczność usuwania metali, związki biogenne, Hippuris vulgaris. 
